\title{
OSOBENOSTI NASTAVE PRAGMATIKE U ITALIJANSKOM KAO J2 NA UNIVERZITETSKOM NIVOU
}

\section{Sažetak}

Poslednjih decenija vođena je diskusija o tome da li je moguće podučavati pragmatiku i traga se i dalje za efikasnim načinima da se to sprovede u učionici J2, čak i uprkos činjenici da su istraživanja iz oblasti primenjene lingvistike na ovu temu sve intenzivnija. Sam opis pragmatičko-diskursne kompetencije u J2 ispoljava manjkavosti, a izdavačka ponuda često ne pridaje dovoljno fokusirane pažnje pragmatičkim obeležjima ciljnog jezika. U radu se predočava mogući način podučavanja odabranih pragmatičkih pojava u italijanskom kao Js na uzorku sačinjenom od studenata III godine beogradske italijanistike (ciljni nivo B1-B2). Ponuđeni okvir nastave pragmatike može poslužiti za skretanje pažnje na nedovoljnu zastupljenost pragmatičkih fenomena u nastavi, ali i kao potvrda uspešnosti njihovog podučavanja i temelj progresivnom, sistematskom uvođenju ovih i sličnih elemenata u nastavni proces.

Ključne reči: nastava pragmatike, italijanski kao J2, diskursni markeri, pragmatičkodiskursna kompetencija, univerzitetski nivo.

\section{Uvod}

Pragmatika, kao novija naučna disciplina, privukla je poslednjih decenija pažnju i primenjenih lingvista i proučavalaca teorije usvajanja drugog jezika. lako su istraživanja iz ovih oblasti na temu pragmatičkih fenomena sve intenzivnija, ipak se i dalje traga za preciznim odgovo-

Filološki fakultet, Studenstki trg 3, 11000 Beograd

n.cekovic@fil.bg.ac.rs 
rima, s jedne strane, u vezi sa tokom samog procesa usvajanja izvesnih pragmatičkih pojava, njihovom sekvencijalnošću i sl., i s druge, u vezi sa načinom na koji ove pojave treba tretirati u učionici drugog jezika, odnosno u prirodnom (J2) ili instrukcionom okruženju (JS). Štaviše, u novije vreme vođena je prilično živa naučna diskusija o tome da li je uopšte moguće podučavati pragmatiku, odnosno da li davanje instrukcija u vezi sa pragmatičkim elementima pomaže sticanje pragmatičke kompetencije (up., npr. Kasper 1997, Rose \& Kasper 2001, Kasper \& Schmidt 1996, Kasper \& Roever 2005). Postavlja se i pitanje na koji način se to može efikasno izvesti, uz kakav vid inputa, ${ }^{1}$ u kakvom okruženju?

\section{Kakav input, u kakvom kontekstu?}

U studijama koje verifikuju korist od instrukcija najčešće se ispituje da li su eksplicitne instrukcije na temu odabranih pragmatičkim fenomena efikasnije od implicitnih (u vezi sa diskursnim markerima (u daljem tekstu DM), up. npr. House \& Kasper 1981, House 1996, Tateyama et al. 1997, De la Fuente 2009), pri čemu se pod implicitnim instrukcijama podrazumeva davanje inputa i prilike za odgovarajuću praksu u vezi sa predmetnom pragmatičkom pojavom, dok se pod onim eksplicitnim podrazumeva i pružanje metajezičkih, teorijskih znanja, kao i sistematskih objašnjenja, npr. o odnosu formi i funkcija. Rezultati ovih istraživanja jasno ukazuju na veću korisnost davanja eksplicitnih metapragmatičkih instrukcija u poređenju sa onim implicitnim, u smislu, npr. upotrebe šireg dijapazona DM kod ispitanika koji su im bili izloženi (House 1996), što ide u prilog opštem zaključku da je davanje instrukcija efikasnije od odsustva instrukcija i fokusa na ciljne odlike $J 2$.

Osim toga, određene studije potvrđuju korist koja se dobija iz pristupa s instrukcijama o pragmatici međujezika u kontekstu drugog (J2) i stranog jezika (JS) (npr. Rose 2000, Rose \& Ng 2001, Alcón Soler 2005), ${ }^{2}$ s tim da, kako navode Tateyama et al. (1997: 163, up. Kasper 1997, Bardovi-Harlig \& Dörnyei 1998), brojni rezultati ipak potvrđuju da okruženje J2 pruža bogatije mogućnosti za razvijanje pragmatičkih sposobnosti kod učenika nego kontekst JS.

1 lako se u domaćoj glotodidaktičkoj literaturi za ovaj pojam koristi i termin jezički priliv (up., npr. Durbaba 2011), preciznosti radi držaćemo se odabranog stranog termina.

2 Up. i popis studija u Tateyama et al. (1997: 163) i u Kasper \& Roever (2005: 322) o razumevanju implikatura, govornim činovima komplimentiranja, izvinjavanja i dr., koje potvrđuju da se većina pragmatičkih fenomena može podučavati. 
Zabeležena su, međutim, mišljenja i da didaktička intervencija, iako podsticajna, ne mora biti i neophodna, kao i da ima fenomena koji odolevaju podučavanju, rezultat su univerzalne pragmatičke kompetencije i pozitivnog transfera iz J1, ili mišljenja koja ukazuju na limitiranu mogućnost podučavanja pragmatike u J2 (npr. Billmyer 1990, up. Tateyama et al. 1997: 165-166, Kasper \& Schmidt 1996: 160). Fung \& Carter (2007: 434) u svakom slučaju ističu da je neophodno fokusiranje pažnje na pragmatičke odlike kako bi se učenje odvilo, pa bilo da je to slučaj u prirodnom ili instrukcionom okruženju.

Didaktička intervencija postaje od presudne važnosti u kontekstu JS budući da je u slučaju njenog izostanka učenik lišen vitalnog izvora i plodnog tla za razvoj svoje pragmatičke kompetencije. Ovakvog smo mišljenja utoliko pre što smo u našem prethodnom radu (Ceković, u štampi) ustanovili oskudnu i nedovoljno fokusiranu pažnju koja se u didaktičkim materijalima posvećuje izvesnim pragmatičkim pojavama (DM, zatvaranje razgovora): uz svega nekolicinu udžbenika za italijanski kao J2, izdvojili smo i par specijalizovanih priručnika pogodnih za tretman DM u učionici (Zamora et al. 2006, Brighetti \& Minuz 2001, Riggenbach 1999). Među njima, po količini pažnje posvećenoj DM, budući da uz frazeologizme oni zauzimaju prioritetno mesto i jedno obimnije poglavlje naročito se izdvaja Zamora et al. (2006), koji će činiti okosnicu naše intervencije.

A ako se takvoj, nefokusiranoj pažnji izdavačke ponude pridoda i, po našem mišljenju (Ceković 2016) manjkav tretman DM u Zajedničkom evropskom okviru (Council of Europe 2001, Savet Evrope 2003), u kom se, iako značajnom kao dokumentu i skupu dragocenih smernica oni ipak nedovoljno precizno tretiraju, bilo upotrebom preširoke kvalifikacije (koheziona sredstva, vezivne reči) ili prevaziđene i neprecizne terminologije u srpskom prevodu (artikulatori (za povezivanje jezičkog izraza)), postaje jasno da na polju definisanja toga u kom pravcu i u kakvom obliku treba sprovoditi didaktičku intervenciju iz oblasti pragmatike ostaje još prostora za dalje delovanje, naročito u pogledu optimizacije pragmatičke intervencije. Bilo bi, zapravo, idealno kada u nastavnoj praksi ne bi ostajalo prostora za proizvoljna tumačenja ovih i sličnih smernica, kao i za nedoumice u pogledu pedagoških implikacija poput: Šta konkretno treba uvrstiti u nastavni proces kako bi učenik razvio ovu kompetenciju? Odnosno: Kako odabrati sadržaje kojima treba podučiti učenike tj. kojim sadržajima 
ih podučiti? Na kojim nivoima kompetencije? U kojoj fazi kurikuluma? Kojim sekvencijalnim redom prezentovati tako odabrane sadržaje? Kako ih integrisati u didaktičku jedinicu?

\section{Metodologija}

Imajući navedeno u vidu, zanimalo nas je da ovim radom predočimo jedan od mogućih načina podučavanja pragmatike $u$ italijanskom kao Js na univerzitetskom nivou koji smo sproveli u delo. ${ }^{3}$ Pri tome, odabrali smo da se fokusiramo na DM kao pragmatički fenomen par excellence: ovi multifunkcionalni razgovorni elementi, reči i izrazi poput allora, cioè, ecco, insomma, quindi i brojnih drugih, predstavljaju odraz učenikove pragmatičko-diskursne kompetencije i pragmatičke fluentnosti (House 2003, 2013), kao i svojevrstan pokazatelj njegove veštine upravljanja interakcijom sa sagovornikom i strukturiranja vlastitog diskursa.

\section{Učesnici}

Slučajan uzorak za ovo istraživanje sačinjen je od 10 srbofonih studenata III godine osnovnih studija italijanskog jezika i književnosti na Filološkom fakultetu Univerziteta u Beogradu, na srednje-naprednom nivou kompetencije (ciljni nivo B1-B2). Svi ispitanici su bili ženskog pola, starosti 19-25 godina, prethodno su učili J2 duže od 2 godine, svi su vladali još i engleskim, ali i nemačkim, poljskim, norveškim, francuskim ili španskim jezikom, kratko su boravili u Italiji, a pored časova, većina je za vreme trajanja instrukcija ostvarivala kontakt sa J2 i preko medija.

\section{Instrukcije}

Istraživanje je sprovedeno tokom jedne akademske godine, tačnije 5. (zimskog) i 6. (letnjeg) semestra, u okviru kursa iz Savremenog italijanskog jezika koji su ispitanici pohađali u trajanju od 4 školska časa ne-

3 Preispitivanje efikasnosti instrukcija nije, međutim, predmet ovog rada. Sama delotvornost ovakvih instrukcija, premda u širem obimu i uz dopunu odgovarajućim materijalima istraživača, ali kojima su obuhvaćene i instrukcije opisane u ovom radu, potvrđena je u Ceković 2016. 
deljno i gde im je nastavu držao istraživač. $U$ redovnoj nastavi tj. nezavisno od samog istraživanja, upotrebljavan je udžbenik Magari i njegov deo namenjen B2 nivou kompetencija, u kome je sadržan mali broj aktivnosti na temu DM: trodelna komplementaciona aktivnost i role-play, dvodelna komplementaciona aktivnost i dramatizacija (De Giuli, Guastalla \& Naddeo 2008: 99, 100, 160; v. detaljniji opis u Ceković, u štampi).

Osim toga, ispitanici su na časovima dobijali i mogućnost praktikovanja govorne produkcije, kao sastavni deo kursa jezika zasnovanog na komunikativnom pristupu. $U$ vezi sa $D M$, ispitanicima je pružan i korektivni feed-back (engl. corrective feed-back) i to najčešće u vidu elicitacije i repeticije (engl. prompts). Korektivni feed-back sprovođen je u usmenoj ili pisanoj formi, individualno ili grupno, u zavisnosti od vrste zadatka na koji se odnosio. ${ }^{4}$

Grupa je povrgnuta instrukcijama u ukupnom trajanju od 10 nedelja, u proseku po 20 minuta nedeljno, u toku trajanja jednog školskog časa: faza instrukcija trajala je 5 uzastopnih nedelja u prvom i 5 uzastopnih nedelja u drugom semestru, između kojih je nastupila višenedeljna pauza u nastavi zbog praznika i ispitnih rokova.

\section{Analiza}

$\mathrm{Na}$ instrukcionom treningu je, kako smo najavili, korišćen didaktički priručnik Hai voluto la bicicletta... grupe autora Zamora et al. (2006: 182206), čime je obuhvaćen širok dijapazon podučavanih formi i funkcija DM predstavljenih u Tabeli 1. U ovom materijalu, kao i u tokom samog didaktičkog procesa identifikovanje karakteristika i funkcija DM izvršeno je prema teorijskom okviru C. Bazzanelle (1994, 1995, nav. u Zamora et al. 2006: 17).

$4 \quad$ Ispitanici su bili naviknuti da u redovnoj nastavi dobijaju od nastavnika korektivni feedback, te su i za vreme trajanja istraživanja i potpuno nezavisno od njega, dobijali povratnu informaciju u vezi sa gramatičkim (fonološkim, morfološkim, sintaksičkim, leksičkim, i dr.) greškama. 


\begin{tabular}{|c|c|}
\hline INTERAKCIONA FUNKCIJA & FORMA \\
\hline Uzimanje reči & allora, ecco \\
\hline Ispunjavanje & $\begin{array}{l}\text { be', cioè, ecco, insomma, niente, } \\
\text { praticamente, sai/sa, vediamo }\end{array}$ \\
\hline Zahtevanje pažnje & ecco, guarda, senti (un po') \\
\hline Fatička funkcija & ragazzi, insomma \\
\hline Modulacija & $\begin{array}{l}\text { capirai, cioè, dai, diciamo (che), ecco, eh, } \\
\text { guarda, hai capito, insomma, mah, niente, } \\
\text { non è che, praticamente, sai/sa, senti, va', } \\
\text { vedi }\end{array}$ \\
\hline Kontrola prijema & ahò, hai sentito? \\
\hline Zahtevanje slaganja i(li) potvrde & no? \\
\hline Ustupanje reči & comunque, ecco, insomma \\
\hline Prekidanje & aspetta, aspetta \\
\hline Back-channelling, potvrđivanje pažnje & e poi?, sì \\
\hline Prijem, spoznaja, zahtevanje objašnjenja & $\begin{array}{l}\text { che!?; che che?; e allora?; e cioè; eh; e } \\
\text { quindi?; ho capito; ok }\end{array}$ \\
\hline Slaganje i(li) potvrda, neslaganje & $\begin{array}{l}\text { appunto, ecco, e dai!, eh sì, eh già, ho } \\
\text { capito, infatti, insomma, ma che!, ma dai, } \\
\text { ma va', perfetto, proprio così, scusa }\end{array}$ \\
\hline METATEKSTUALNA FUNKCIJA & FORMA \\
\hline Demarkacija & cioè, ecco, insomma, \\
\hline Fokalizacija & ecco, eh, guarda, hai capito, senti, $v a^{\prime}$ \\
\hline Reformulacija & anzi, cioè, ossia, quindi, voglio dire \\
\hline
\end{tabular}

Tabela 1. Forme i funkcije diskursnih markera obuhvaćene instrukcijama (Zamora et al. 2006)

Poseban akcenat u ovom priručniku, koji kombinuje teorijska razmatranja sa predlozima za operativan didaktički pristup i namenjen je učenicima na intermedijalno-naprednom nivou znanja, stavljen je na polifunkcionalnost sledećih formi: insomma (ispunjavanje, fatička funkcija, modulacija, ustupanje reči, neslaganje, demarkacija), ecco (uzimanje reči, ispunjavanje, zahtevanje pažnje, modulacija, ustupanje reči, slaganje i potvrda, demarkacija, fokalizacija), zatim anzi (reformulacija: parafraza, autokorekcija) i cioè (ispunjavanje, modulacija, demarkacija, reformulacija). Ostali navedeni primeri polifunkcionalnosti su: eh (modulacija, fokalizacija), guarda (zahtevanje pažnje, modulacija, fokalizacija), ho capito (prijem i spoznaja, neslaganje, fokalizacija), niente (ispunjavanje, modulacija), praticamente 
(ispunjavanje, modulacija), sai/sa (ispunjavanje, modulacija), senti (zahtevanje pažnje, modulacija, fokalizacija), $v a^{\prime}$ (modulacija, fokalizacija).

U Zamora et al. (2006) sadržano je i u instrukcijama upotrebljeno svih 10 didaktičkih jedinica iz odeljka o DM, grupisanih u zavisnosti od pojedinačnih funkcija ili formi na koje su fokusirane. Pregled ciljeva pojedinačnih instrukcionih časova, usklađenih sa Silabusom kursa koji su ispitanici pohađali odnosno sa zadatim temama, prikazan je u Tabeli 2a (prvi semestar) i Tabeli $2 b$ (drugi semestar).

\begin{tabular}{|c|c|c|c|c|}
\hline Čas & Tema & Materijal & $\begin{array}{l}\text { Ciljne forme } \\
\text { i funkcije }\end{array}$ & Tip i svrha aktivnosti \\
\hline 1. & $\begin{array}{l}\text { Lingua: } \\
\text { maschio e } \\
\text { femmina }\end{array}$ & $\begin{array}{l}\text { 1. Segnali e funzioni } \\
\text { (Zamora et al. 2006: } \\
\text { 182-184) }\end{array}$ & $\begin{array}{l}16 \text { formi } \\
\text { i većina } \\
\text { funkcija }\end{array}$ & $\begin{array}{l}\text { slušanje i čitanje, generalni } \\
\text { opis formi i funkcija }\end{array}$ \\
\hline 2. & $\begin{array}{l}\text { Storia: } \\
\text { l'era } \\
\text { Berlusconi }\end{array}$ & $\begin{array}{l}\text { 2. Ci sto! / Non ci sto! } \\
\text { (Zamora et al. 2006: } \\
\text { 185-187) }\end{array}$ & (ne)slaganje & $\begin{array}{l}\text { slušanje i čitanje, uočavanje } \\
\text { formi i fokusiranje na } \\
\text { intonaciju kojom se } \\
\text { izgovaraju; kombinacione i } \\
\text { komplementacione vežbe, } \\
D C T\end{array}$ \\
\hline 3. & $\begin{array}{l}\text { Storia: } \\
\text { l'era } \\
\text { Berlusconi }\end{array}$ & $\begin{array}{l}\text { 2. Ci sto! / Non ci sto! } \\
\text { (Zamora et al. 2006: } \\
\text { 187-190) }\end{array}$ & (ne)slaganje & $\begin{array}{l}\text { slušanje i čitanje, uočavanje } \\
\text { formi i fokusiranje na poziciju } \\
\text { u iskazu, } D C T \text {, višestruk izbor, } \\
\text { kombinaciona vežba }\end{array}$ \\
\hline 4. & $\begin{array}{l}\text { Arti: giallo } \\
\text { italiano }\end{array}$ & $\begin{array}{l}\text { 3. Enfatizzo o } \\
\text { minimizzo (Zamora et } \\
\text { al. 2006: 190-192) }\end{array}$ & $\begin{array}{l}\text { modulacija, } \\
\text { fokalizacija }\end{array}$ & $\begin{array}{l}\text { slušanja i čitanje, } \\
\text { kombinacione vežbe }\end{array}$ \\
\hline 5. & $\begin{array}{l}\text { Arti: giallo } \\
\text { italiano }\end{array}$ & $\begin{array}{l}\text { 4. Non ho capito, } \\
\text { spiegati meglio! } \\
\text { (Zamora et al. 2006: } \\
\text { 192-194) }\end{array}$ & $\begin{array}{l}\text { zahtevanje } \\
\text { objašnjenja }\end{array}$ & $\begin{array}{l}\text { slušanje i čitanje, višestruk } \\
\text { izbor, DCT }\end{array}$ \\
\hline
\end{tabular}

Tabela 2a. Pregled ciljeva instrukcionih časova (prvi semestar)

$5 \quad$ Na ovom času DM su obrađivani i u okviru redovne nastave, kroz didatičku jedinicu sadržanu u udžbeniku Magari (De Giuli, Guastalla \& Naddeo 2008: 99-100), gde se, kako smo naveli, javljaju slušanje s višestrukim izborom i komplementacionim aktivnostima, kao i role-play. 


\begin{tabular}{|l|l|l|l|l|}
\hline Čas & Tema & Materijal & $\begin{array}{l}\text { Ciljne forme i } \\
\text { funkcije }\end{array}$ & Tip i svrha aktivnosti \\
\hline 6. & $\begin{array}{l}\text { Geografia: } \\
\text { mari e monti }\end{array}$ & $\begin{array}{l}\text { 5. Cioè... cosa dire } \\
\text { e come pianificare? } \\
\text { (Zamora et al. 2006: } \\
\text { 194-195) }\end{array}$ & $\begin{array}{l}\text { interakcioni } \\
\text { markeri, } \\
\text { ispunjivači }\end{array}$ & slušanje i čitanje, DCT \\
\hline 7. & $\begin{array}{l}\text { Società: } \\
\text { periferia e } \\
\text { architettura }\end{array}$ & $\begin{array}{l}\text { 6. Vogliamo essere } \\
\text { precisi? (Zamora et } \\
\text { al. 2006: 195- 197) }\end{array}$ & $\begin{array}{l}\text { metatekstualni } \\
\text { markeri, } \\
\text { reformulatori }\end{array}$ & $\begin{array}{l}\text { slušanje i čitanje, } \\
\text { višestruk izbor, refleksija } \\
\text { i komplementaciona } \\
\text { vežba, DCT }\end{array}$ \\
\hline 8. & $\begin{array}{l}\text { Società: } \\
\text { periferia e } \\
\text { architettura }\end{array}$ & $\begin{array}{l}\text { 7. Segnali che sono } \\
\text { verbi (Zamora et al. } \\
\text { 2006: 198-201) }\end{array}$ & $\begin{array}{l}\text { DM poreklom } \\
\text { od glagolskih } \\
\text { oblika }\end{array}$ & $\begin{array}{l}\text { slušanja i čitanje, } \\
\text { višestruk izbor, } \\
\text { komplementaciona } \\
\text { vežba, DCT }\end{array}$ \\
\hline 9. & Arti: cinema & $\begin{array}{l}\text { 8. Insomma, quante } \\
\text { funzioni! (Zamora et } \\
\text { al. 2006: 201-203), 9. } \\
\text { Ecco è dappertutto! } \\
\text { (Zamora et al. 2006: } \\
\text { 203-205) }\end{array}$ & $\begin{array}{l}\text { insomma, ecco } \\
\text { 10. Facciamo il punto } \\
\text { della situazione } \\
\text { (Zamora et al. 2006: } \\
\text { 205-207) }\end{array}$ & $\begin{array}{l}\text { razne forme i } \\
\text { višestruk izbor, DCT }\end{array}$ \\
\hline funkije & Arti: cinema, diskusija \\
\hline
\end{tabular}

Tabela 2b. Pregled ciljeva instrukcionih časova (drugi semestar)

Obrađene didaktičke jedinice uglavnom su strukturirane prema trima fazama procesa učenja: prezentacija - analiza i refleksija - produkcija, i u njima su zastupljene tipološki različite didaktičke aktivnosti.

Uvodna jedinica služi kreiranju generalne slike o tome šta su DM i koje su im funkcije, a završna rekapitulaciji i verifikovanju usvojenog znanja, između ostalog i kroz replike iz originalnih italijanskih filmova. Ostale jedinice započinju prezentovanjem DM unutar kratkih, polu-autentičnih dijaloga čime se omogućava njihova kontekstualizacija (aktivnost sa slušanjem i čitanjem transkribovanih dijaloga u kojima su istaknute ciljne forme). Nakon što učenik usvoji fome i shvati njihovo značenje slede aktivnosti koje mu omogućavaju da ih analizira i memoriše (kombinacione, zasnovane na kombinovanju replika govornika i sagovornika i ponuđenih 
formi DM; refleksija, npr. o analognim formama). Jedinice se završavaju aktivnostima vođene ili slobodne produkcije koje omogućavaju verifikovanje usvojenosti date građe od strane učenika, kao i sposobnosti njenog samostalnog reprodukovanja u odgovarajućm kontekstu (višestruk izbor; komplementacione, koje se sastoje u dopunjavanju dijaloga odgovarajućim formama; konstrukcione tj. engl. discourse-completion task (DCT), vođena rekonstrukcija replika (sa)govornika). Cilj svih ovih aktivnosti, u proseku 4 po didaktičkoj jedinici, jeste da se kod studenta razvije sposobnost kontekstualizovane upotrebe DM, najpre kroz receptivne, a zatim i produktivne jezičke veštine, s fokusom na svrsishodnu i progresivnu tj. što veću i slobodniju upotrebu DM u njegovom oralnom outputu. U Prilogu 1 nalazi se primer jedne didaktičke jedinice iz ovog priručnika (Zamora et al. 2006: 192-193) u kojoj su ilustrovane pomenute faze kroz tri didaktičke aktivnosti (prikazane, zbog ograničenog prostora, u redukovanom obliku).

$\mathrm{U}$ instrukcijama je, pored toga, korišćen i materijal koji je istraživač sastavio u svrhu rekapitulacije gradiva (u pitanju su kombinaciona vežba i višestruk izbor), vodeći računa da on bude dobro inkorporiran u instrukcioni trening i sadržaje redovnog kursa, kao i da bude prilagođen jezičkim potrebama i sposobnostima ispitanika. Ovaj materijal nalazi se u Prilogu 2.

\section{Diskusija}

Prema hipotezama, učeniku mora biti pružen razumljiv input (engl. comprehensable input, Krashen 1981, 1982) kako bi se odvilo usvajanje, s ciljem da se input asimiluje (engl. intake) i produktivno manifestuje (engl. output, Swain \& Lapkin 1995, Swain 2005), a naporedo sa sekvencijalnošću u usvajanju, utvrđena je i sekvencijalnost u pružanju inputa. $U$ domenu učenja J2 uvreženo je, naime, mišljenje da razvoju produktivnih veština treba da prethodi rad na razvijanju onih receptivnih (Canale 1983) i da produkcija treba da bude odložena do momenta kada se za to stvore odgovarajući, prirodni uslovi (McCarthy 1998).

Proces podučavanja DM može se stoga odvijati od više ka manje kontrolisanim aktivnostima (Zorzi 2001), odnosno započeti vežbama kojima se kod učenika budi i uvećava svest (engl. consciousness-raising activities, Willis \& Willis 1996) tj. u kojima se on podstiče da postepeno sam 
otkriva i razvija svest o tome kako markeri funkcionišu, a zatim i razvija sposobnost da uviđa i fokusira svoju pažnju na datu pojavu (engl. noticing, Schmidt 1990, 1993), koja mu se prezentuje dovoljno učestalo (engl. frequency, Hatch \& Wagner-Gough 1976) nakon čega mogu uslediti aktivnosti koje učeniku nude mogućnost za komunikativnu praksu. ${ }^{6}$ Proces se može bazirati na konkretnim zadacima (engl. task-based instruction) i upotpuniti vežbama s ciljem popunjavanja praznina (engl. gap-fill), gde učenik npr. konsultuje korpus kao izvor informacija o pojedinačnom markeru kojim treba da popuni prazninu nastalu njegovom eliminacijom iz transkripta autentičnog dijaloga, ili aktivnostima u kojima se poseže za učenikovim maternjim jezikom, tako što mu se, pre nego što se pozabavi markerima u J2, pomaže najpre da shvati da oni postoje i imaju značajne funkcije u J1, vrši se poređenje J1 i J2, nalaže učenikovo oslanjanje na intuiciju i resurse iz maternjeg jezika (Zorzi 2001).

Andersen (1990: 58) smatra da se usvajanje odnosa formi i funkcija može olakšati veštačkim povećanjem učestalosti forme u inputu, kao i da pomenuti odnos treba učiniti što transparentnijim, isključujući privremeno iz inputa oblike koji su manje transparentni, i navodi da je upravo to ono što većina nastavnika i udžbenika nastoje da urade. $U$ pogledu pedagoških implikacija bitno je otkriti forme i značenja koja učenik najpre percipira i inkorporira u svoj međujezik, prilagođavati kompleksnost inputa učenikovim sposobnostima procesiranja i omogućiti da input prati prirodan razvojni put, ka dostizanju jednog muliformnog i multifunkcionaInog sistema kakav je kod maternjih govornika (Andersen 1990).

Ovakva zapažanja, zajedno sa ponuđenim okvirom nastave pragmatike iz ovog rada mogu poslužiti pre svega za skretanje pažnje na nedovoljnu zastupljenost pragmatičkih fenomena u nastavi, ali i kao potvrda uspešnosti njihovog podučavanja i temelj progresivnom, sistematskom uvođenju ovih i sličnih jezičkih elemenata u nastavni proces.

\section{Izvori i literatura}

$6 \quad$ Kasper (1997) i Bardovi-Harlig i Dörnyei (1998) smatraju da se niz aktivnosti koje su se pokazale korisnim za pragmatički razvoj suštinski mogu podvesti pod ove dve kategorije tj. vežbe kojima se ostvaruje uvećanje pragmatičke svesti i one koje omogućavaju komunikativnu praksu. 
Alcón Soler, Eva. "Does instruction work for learning pragmatics in the EFL context?" System 33 (2005): 417-435. Web. 25. 06. 2018.

Andersen, Roger. "Models, Processes, Principles and Strategies: Second language Acquisition Inside and Outside the Classroom". Bill VanPatten \& James Lee (eds.). Second Language Acquisition/Foreign Language Learning. Clevendon: Multilingual Matters, 1990. 45-68. Printed.

Bardovi-Harlig, Kathleen, \& Zoltán Dörnyei. "Do Language Learners Recognize Pragmatic Violations? Pragmatic Versus Grammatical Awareness in Instructed L2 Learning". TESOL Quarterly 32 (2) (1998): 233-262. Web. 25. 06. 2018.

Bazzanella, Carla. Le facce del parlare. Un approccio pragmatico all'italiano parlato. Firenze: La Nuova Italia, 1994. Printed.

Bazzanella, Carla. "I segnali discorsivi". Lorenzo Renzi, Giampaolo Salvi \& Anna Cardinaletti (eds.). Grande grammatica italiana di consultazione, vol. 3. Bologna: II Mulino, 1995. 225-257. Printed.

Billmyer, Kristine. "I really like your lifestyle: ESL Learners Learning How to Compliment". Penn Working Papers in Educational Linguistics 6 (2) (1990): 31-48. Web. 25. 06. 2018.

Brighetti, Claudia, \& Fernanda Minuz. Abilità del parlato. Torino: Paravia, 2001. Printed. Canale, Michael. "From communicative competence to communicative language pedagogy". Jack C. Richards \& Richard W. Schimdt (eds.). Language and communication. London: Longman, 1983. 2-27. Printed.

Ceković, Nevena. Diskursni markeri u govornoj produkciji na italijanskom kao drugom jeziku (Doktorska disertacija). Beograd: Filološki fakultet, 2016. Štampano.

Ceković, Nevena. „Didaktički materijali za italijanski kao L2: (ne)eksplicitni fokus na diskursnim markerima". Anali Filološkog fakulteta 30 (1) (u štampi).

Council of Europe. Common European Framework of Reference for Languages: Learning, teaching, assessment. Cambridge: Cambridge University Press, 2001. Printed.

De Giuli, Alessandro, Carlo Guastalla \& Ciro Massimo Naddeo. Magari. Corso di lingua e cultura italiana di livello intermedio e avanzato (B1/C1). Firenze: Alma, 2008. Printed.

De la Fuente, María José. "The Role of Pedagogical Tasks and Focus on Form in Acquisition of Discourse Markers by Advances Language Learners". Ronald P. Leow, Héctor Campos \& Donna Lardiere (eds.). Little words. Their History, Phonology, Syntax, Semantics, Pragmatics, and Acquisition. Washington, D. C.: Georgetown University Press, 2009. 211-221. Printed.

Durbaba, Olivera. Teorija i praksa učenja i nastave stranih jezika. Beograd: Zavod za udžbenike, 2011. Štampano.

Fung, Loretta, \& Ronald Carter. "Discourse Markers and Spoken English: Native and Learner Use in Pedagogic Settings". Applied Linguistics 28 (3) (2007): 410-439. Web. 25. 06. 2018.

Hatch, Evelyn, \& Judy Wagner-Gough. "Explaining sequence and variation in second language acquisition". Language Learning 4 (1976): 39-47. Web. 25. 06. 2018.

House, Juliane. "Developing Pragmatic Fluency in English as a Foreign Language: Rou- 
tines and Metapragmatic Awareness". Studies in Second Language Acquisition 18 (2) (1996): 225-252. Web. 25. 06. 2018.

House, Juliane. "Teaching and learning pragmatic fluency in a foreign language: the case of English as a lingua franca". Alicia Martínez Flor, Ester Usó Juan \& Ana Fernández Guerra (eds.). Pragmatic Competence and Foreign Language Teaching. Castelló de la Plana: Publicacions de la Universitat Jaume I, 2003. 133-160. Printed.

House, Juliane. "Developing pragmatic competence in English as a lingua franca: Using discourse markers to express (inter)subjectivity and connectivity". Journal of Pragmatics 59 (2013): 57-67. Web. 25. 06. 2018.

House, Juliane, \& Gabriele Kasper. "Zur Rolle der Kognition in Kommunikationskursen". Die Neueren Sprachen 80 (1981): 42-55. Web. 25. 06. 2018.

Kasper, Gabriele. "Can pragmatic competence be taught". NetWork 6 (1997): 105-119. Web. 25. 06. 2018.

Kasper, Gabriele, \& Richard Schmidt. "Developmental issues in interlanguage pragmatics". Studies in Second Language Acquisition 18 (1996): 149-169. Web. 25. 06. 2018.

Kasper, Gabriele, \& Carsten Roever. "Pragmatics in Second Language Learning". Eli Hinkel (ed.). Handbook on research in second language teaching and learning. Mahwah, NJ/London: Lawrence Erlbaum, 2005. 317-334. Printed.

Krashen, Stephen D. Second Language Acquisition and Second Language Learning. Oxford: Pergamon Press, 1981. Printed.

Krashen, Stephen D. Principles and Practice in Second Language Acquisition. Oxford: Pergamon Press, 1982. Printed.

McCarthy, Michael. Spoken language and applied linguistics. Cambridge: Cambridge University Press, 1998. Printed.

Riggenbach, Heidi. Discourse Analysis in the Language Classroom. The Spoken Language, vol. 1. Ann Arbor, MI: University of Michigan Press, 1999. Printed.

Rose, Kenneth. "An exploratory cross-sectional study of interlanguage pragmatic development". Studies in Second Language Acquisition 22 (1) (2000): 27-67. Web. 25. 06. 2018.

Rose, Kenneth, \& Gabriele Kasper (eds.). Pragmatics in Language Teaching. Cambrigde: Cambridge University Press, 2001. Printed.

Rose, Kenneth, \& Connie Ng. "Inductive and deductive teaching of compliments and compliment responses". Kenneth Rose \& Gabriele Kasper (eds.). Pragmatics in Language Teaching. Cambrigde: Cambridge University Press, 2001. 145-170. Printed.

Savet Evrope. Zajednički evropski okvir za žive jezike. Učenje, nastava, ocjenjivanje. Podgorica: Ministarstvo prosvjete i nauke, 2003. Štampano.

Schmidt, Richard. "The role of Consciousness in Second Language Learning". Applied Linguistics 11 (2) (1990): 129-158. Web. 25. 06. 2018.

Schmidt, Richard. "Consciousness, Learning and Interlanguage Pragmatics". Gabriele Kasper \& Shoshana Blum-Kulka (eds.). Interlanguage Pragmatics. New York/Oxford: Oxford University Press, 1993. 21-42. Printed. 


\section{Култура универзитета и филологија}

Swain, Merrill. "The Output Hypothesis: Theory and Research". Eli Hinkel (ed.). Handbook on research in second language teaching and learning. Mahwah, NJ/London: Lawrence Erlbaum, 2005. 471-484. Printed.

Swain, Merrill, \& Sharon Lapkin. "Problems in Output and the Cognitive Processes They Generate: A Step towards Second Language Learning". Applied Linguistics 16 (1995): 371-391. Web. 25. 06. 2018.

Tateyama, Yumiko, Gabriele Kasper, Laura P. Mui, Hui-Mian Tay, \& Ong-on Thananart. "Explicit and implicit teaching of pragmatic routines". Lawrence F. Bounton (ed.). Pragmatics and Language Learning, vol. 8. Urbana, Illinois: University of Illinois, 1997. 163-177. Printed.

Willis, David, \& Jane Willis. "Consciousness-raising activities". Jane Willis \& David Willis (eds.). Challenge and Change in Language Teaching. Oxford: Macmillan Heinemann, 1996. 63-76. Printed.

Zamora, Pablo, Alessandro Arianna, Eleonora Ioppoli, \& Federica Simone. Hai voluto la bicicletta... Esercizi su fraseologia e segnali discorsivi per studenti di italiano LS/ L2. Perugia: Guerra, 2006. Printed.

Zorzi, Daniela. (2001). "The pedagogic use of spoken corpora. Learning discourse markers in Italian". Guy Aston (ed.). Learning with corpora. Houston: Athelstan. 85107. Printed. 
Prilog 1. Primer didaktičke jedinice iz Zamora et al. (2006: 192-193)

\section{NON HO CAPITO, SPIEGATI MEGLIO! \\ I ENTRIAMO IN TEMA!}

I-1. Ecco evidenziati in neretto un gruppo di segnali discorsivi che servono per chiedere all'interlocutore di essere più chiaro e preciso, di ripetere e/o spiegare meglio cosa sta dicento. Ascolta e poi leggi ad alta voce i seguenti dialoghi.

1) Franco: E allora che?

Arturo: Che che?

Franco: La cena con Silvia! Voglio dire, come è andata ieri?

2) Anna: Ho parlato con Mario.

Rodolfo: E quindi? Che c'entra adesso Mario?

Anna: Non mi avevi detto di chiedergli se vendeva la moto? Ha detto di sì, ma a me sembra un po' cara. [...]

\section{COMPLETIAMO!}

II-1. Completa i seguenti dialoghi scegliendo il segnale discorsivo opportuno tra quelli elencati nelle tre opzioni.

1) Luciano: Anna e Fabio si sposano.

Maria:

A me quei due non mi sono mai stati simpatici.

Luciano: Neanche a me sono tanto simpatici, ma se ci invitano al matrimonio, dobbiamo andarci.
a) Che che?
b) Insomma
c) E allora?

2) Antonio: Amore! Oggi ho vinto duecento euro alle corse dei cavalli!

Anna:

Antonio: Sì, ma poi ne ho persi trecento a poker...
a) E cioè?
b) Mah....
c) Che!? [...]

\section{ORA TOCCA A TE!}

III-1. Scrivi i dialoghi seguendo le indicazioni fornite nelle tracce.Usa i segnali discorsivi opportuni tra quelli visti nell'esercizio 1-1 per chiedere all'interlocutore di essere più chiaro, di usare parole più semplici, oppure di spiegare le cause di un evento o di un atteggiamento.

1) Gianni: "Per fare la chiocciola devi cliccare Alt Gr e 2".

Traccia: Mario, non molto esperto di informatica, non sa cosa significhi "cliccare" e Gianni riformula l'enunciato usando il verbo "premere".

Mario:

Gianni:

2) Datore di lavoro: "Da domani non è più richiesta la sua presenza in ufficio, resti a casa". Traccia: L'impiegato non ha capito perché non debba andare in uffcio e il datore di lavoro, spietato e insensibile, gli dice che lo ha licenziato.

Impiegato:

Datore di lavoro: 
Prilog 2. Didaktička aktivnost: kombinaciona vežba i višestruk izbor (materijal istraživača, prema Zamora et al. 2006: 182-208)

Nome e cognome

Data ESERCIZI DI RIEPILOGO

I-Ricostruisci i dialoghi unendo le battute della colonna A con quelle della colonna B introducendo la seconda battuta con il segnale discorsivo adeguato.

\begin{tabular}{|c|c|c|}
\hline A & $\begin{array}{l}\text { Segnali } \\
\text { discorsivi }\end{array}$ & B \\
\hline $\begin{array}{l}\text { 1.A Lourdes ho comprato una statuina per la } \\
\text { zia suora. }\end{array}$ & a. Infatti & $\begin{array}{l}\text { a. Non fai altro che lavorare! Ogni } \\
\text { tanto ci vuole anche un po' di svago. }\end{array}$ \\
\hline $\begin{array}{l}\text { 2. C'eri anche te alla famosa cena di Gianna, } \\
\text { quella con la salsa rosa scaduta? }\end{array}$ & $\begin{array}{l}\text { b. Ma } \\
\text { insomma }\end{array}$ & $\begin{array}{l}\text { b. Le solite cose: parenti e } \\
\text { amici, cena al ristorante e tante } \\
\text { fotografie. }\end{array}$ \\
\hline 3. Mi sa che non farò cambiare idea a Marco. & c. Ecco & $\begin{array}{l}\text { c. Mi hanno detto di lasciare } \\
\text { il curriculum e che mi faranno } \\
\text { sapere. }\end{array}$ \\
\hline $\begin{array}{l}\text { 4. Lunedì ho una riunione, martedì un pranzo di } \\
\text { lavoro e poi devo andare a Parigi per incontrare i } \\
\text { clienti giapponesi. Sono stanco morto! }\end{array}$ & d. Appunto & $\begin{array}{l}\text { d. Non potevi scegliere un regalo } \\
\text { più azzeccato. La farai contenta. }\end{array}$ \\
\hline 5. Com'era la festa di laurea di Marina? & $\begin{array}{l}\text { e. Be', } \\
\text { diciamo che... }\end{array}$ & $\begin{array}{l}\text { e. Poche ore dopo eravamo tutti } \\
\text { all'ospedale per un'intossicazione } \\
\text { alimentare. }\end{array}$ \\
\hline $\begin{array}{l}\text { 6. Che ne pensi di Luisa? A me pare } \\
\text { insopportabile. }\end{array}$ & f. Mah... & f. II ragazzo si sa divertire. \\
\hline 7. Allora, com'è andato il colloquio di lavoro? & g. Insomma... & $\begin{array}{l}\text { g. lo direi che non è molto } \\
\text { tollerante. }\end{array}$ \\
\hline $\begin{array}{l}\text { 8. Allora, com'è andata la serata organizzata } \\
\text { da Giulio? Vi ha portato in una di quelle } \\
\text { discoteche che conosce lui? }\end{array}$ & h. Niente... & $\begin{array}{l}\text { h. Ha una forte personalità e non si } \\
\text { fa influenzare da nessuno.. }\end{array}$ \\
\hline
\end{tabular}

\section{$\underline{\text { II - Completa i seguenti dialoghi scegliendo il segnale discorsivo opportuno tra quelli elencati }}$} nelle tre opzioni.

1. Luciano: Anna e Fabio si sposano.

Maria: A me quei due non mi sono mai stati simpatici. Luciano: Neanche a me sono tanto simpatici, ma se ci invitano al matrimonio, dobbiamo andarci.
a. Che che?
b. Insomma
c. E allora? 
2. Antonio: Amore! Oggi ho vinto duecento euro alle corse dei cavalli!

Anna:

Antonio: Sì, ma poi ne ho persi trecento a poker...
a. E cioè!
b. Mah...
c. Che!?

3. Emanuele: Domani devo essere in aeroporto alle cinque di mattina, il mio volo parte alle sei. Ma a quell'ora non ci sono autobus.

Paolo: Come pensi di fare?

Emanuele: $\mathrm{Be}^{\prime} . .$. Diciamo che se qualcuno, ad esempio un caro amico, fosse così gentile da accompagnarmi, io gliene sarei infinitamente grato...
a. E quindi?
b. Niente...
c. Insomma

4. Mamma: E allora che? Racconta!

Figlio:

Mamma: Il colloquio di lavoro! Che ti hanno detto, ti assumono?
a. E quindi?
b. Guarda
c. Che che?

5. Lara: Ho parlato con Daniele. Ha detto che non si fa niente.

Federica: Che significa?

Lara: Significa che niente settimana bianca quest'anno: i suoi genitori vogliono ristrutturare la casa in montagna, quindi non ci possiamo andare.
a. Eh sì...
b. E cioè?
c. Proprio così.

$\underline{\text { III - Individua la funzione del segnale discorsivo in ognuno di questi casi: }}$

1. A: Certo che non sei molto pratico di "fai da te": I'ultima volta che hai provato ad appendere un quadro hai fatto un buco gigantesco.

B: Insomma, in poche parole, vorresti dire che sono un imbranato!
a. riassuntivo
b. continuativo
c. richiesta di spiegazione

2. A: Bella Sofia, eh?

B: Insomma, non male, è la tipica mediterranea, ma a me piacciono di più le nordiche.
a. rafforzativo
b. riempitivo
c. mitigativo

3. A: Come si fanno gli spaghetti aglio, olio e peperoncino?

B. Niente, basta cuocere gli spaghetti, aggiungerci l'aglio, l'olio, il peperoncino soffritti, e se vuoi il formaggio, insomma, molto semplice. Persino tu li puoi preparare senza fare danni.
a. attenzione in corso
b. riassuntivo
c. anticipatore di domanda 


\section{Култура универзитета и филологија}

A: Allora... insomma...che si fa?

B: Boh, tu che dici?
a. riempitivo
b. anticipatore di replica
c. rafforzativo

5. A: Cosa hai? Non ti senti tanto bene?

B: No, niente, insomma, queste giornate grigie mi fanno venire una tristezza...
a. mitigativo/anticipatore di spiegazione
b. continuativo
c. richiesta d’attenzione

6.. A: Scusa, ti ho interrotto, continua pure.

B: Ecco, come ti dicevo, ero in ufficio quando...
a. riassuntivo
b. riprendere il turno
c. minimizzare ciò che si sta per dire

7. A: Stasera non posso uscire perché devo studiare, ho un esame tra due giorni.

$B$ : Ecco, a proposito, quando è che ti laurei?

A: Di esami me ne mancano pochi, ma anche la voglia di darli...
a. rafforzativo
b. riassuntivo
c. richiesta di attenzione

8. A: La conferenza, come ti è sembrata?

B: Mi sono addormentata, ti dico solo questo, ecco.
a. continuativo
b. riempitivo
c. Rafforzativo 


\section{Nevena P. Ceković}

\section{TEACHING PRAGMATICS IN L2 ITALIAN AT THE UNIVERSITY LEVEL}

\section{Summary}

There has been a lively academic discussion in the past several decades on whether it is possible to teach pragmatics, and the researchers are still looking for effective ways of implementing it in a L2 classroom, despite the fact that the research in the Applied Linguistics and the Second Language Acquisition Theory has been intensifying. The description of the pragmatic-discourse competence in $\mathrm{L} 2$ reveals shortcomings and the available published efforts rarely pay due attention to the pragmatic features of the target language. The paper presents one of the possible ways of teaching the selected pragmatic phenomena in FL Italian on a sample composed of the students of the third year of the Italian studies at the University of Belgrade (target level B1-B2). The framework for teaching pragmatics offered in this paper can be used primarily to draw attention to an insufficient presence of the pragmatic phenomena in the instructions, but also as a confirmation of their successful teaching as well as a basis for a gradual, systematic introduction of these and similar language elements in the teaching process.

Key words: pragmatics, L2 Italian, discourse markers, pragmatic-discourse competence, university level. 